a practical account, the other explores in more detail the conceptual framework of values, belief and faith in relation to ethical decision-making.

I was disappointed in not finding a focused discussion about the increasingly potent participation by the community at large in debating medico-moral matters and in determining what is acceptable. In this connection media publicity given to so-called "human interest stories" (often requiring intrusive journalism) and to melodramatic presentation needs critical evaluation.

The book is well produced, and is reasonably priced. I recommend it as a stimulating textbook which is also a valuable source of state-of-the-game information and opinion.

THOMAS E OPPE Emeritus Professor of Paediatrics

\section{Advance Statements about Medical Treatment. Code of Practice with Explanatory Notes}

British Medical Association, London, BMJ Publishing Group, 1995, 39 pages, $£ 5.95$ sc, $£ 4.95$, BMA members.

Spontaneity in social change is fine. It is better for a little professional steering at the right time to keep it on viable paths. A new relationship between doctors and patients is coming about, through changed attitudes on both sides. In the United Kingdom it has not yet, despite loose use of language, degenerated into the conflict of "rights" as is experienced elsewhere, notably in the USA. Enough patients to matter wish to be participant as well as receptive in medical decisions, especially about interventions to prolong life. Doctors have abated their allout enmity to death: in place of aggressive treatment to the end they cultivate palliative medicine and recognise again, as of old, medical futility. Shared decision-making has thus become possible, when both parties are competent to decide. But at the critical time one party (at least) may not be competent, in a given clinical condition. Hence the need for, and the growing acceptance of, advance statements about the sort of treatment the patient would wish to have when that time comes. The BMA's code of practice comes opportunely to give a firm steering hand to this development.

Behind it stands a report of the Law Commission which rather favours giving statutory authority to "anticipatory decisions" and a report of the House of Lords Select Committee on Medical Ethics which would rather have no such authority. There is also discussion in the literature: witness the reviews in this journal. ${ }^{1}$

The BMA title has advance statements, not directives. The guidelines are at their admirable best in distinguishing what patients may reasonably and lawfully ask for and what they may not. They attach (as the law does) binding force only to refusals of treatment, not to requests for specific treatments, which must remain within medical discretion: doctors may not be obliged to violate clinical judgment, conscience or the law. A valid refusal of, say, cardio-pulmonary resuscitation or artificial life support must be honoured provided that the circumstances at the critical time match those envisaged when the statement was signed; and not otherwise. Even a refusal can be overruled when third party interests are threatened: those, for example, of a viable fetus in the womb, or of carers put at risk by a refusal of basic nursing care. "Personal autonomy, although important, cannot always be an over-riding ethical principle." Let that be said again.

Hence the importance of a clear understanding at the time of drafting an advance directive. Given the range of uncertainty about future indications, patients considering advance statements will benefit from professional help. General practitioners are envisaged as most apt to sustain the quality of discussion which will result in an effective statement: that is, one $\overrightarrow{0}$ which will satisfy at once the patient's settled wish and the doctor's professional duty. This excellent booklet offers detailed guidance to this end.

\section{Reference}

1 Saunders J [book review]. Advance directives and the pursuit of death with dignity by Cantor, NL. Fournal of Medical Ethics 1995; 2: 126. Dickenson D [book review]. The troubled dream of life: living with mortality. Fournal of Medical Ethics 1995; 3: 188-9.

G R DUNSTAN Department of Theology, The University of Exeter

\section{Books: information and orders}

If you wish to order or require further information regarding the titles reviewed here, please write to or telephone the BMJ Bookshop, PO Box 295, London WC1H 9JR. Tel: 0171383 6244. Fax: 01713836662. Books are supplied post free in the UK and for BFPO addresses. Overseas customers should add 15 per cent for postage and packing. Payment can be made by cheque in sterling drawn on a UK bank or by credit card (Mastercard, Visa, or American Express, stating card number, expiry date, and full name (The $N$ price and availability are occasionally subject to revision by the publishers).

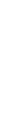

